\title{
A COMPARISON OF DIFFERENT PASTURE ROTATIONS
}

\author{
N. M. Tainton* \\ A gronomy Department, M assey U niversity
}

\section{INTRODUCTION}

ThE Results of cutting trials which have been designed to provide information on grazing frequency and intensity in pasture rotations have, in both temperate and tropical regions, often shown that lax and infrequent cutting promotes higher dry matter production than does more intensive and frequent cutting, except on prostrate rhizomatous and stoloniferous pastures These results have, however, seldom been successfully translated into increased animal production where the negative association frequently observed between dry matter production and both herbage quality and the degree of utilization of the dry matter produced often negates the increased production resulting from lax and infrequent grazing. Added to this are the longer term effects of spelling interval and grazing intensity on sward density and botanical composition, these effects varying through the season as the morphological condition of the pasture species changes:

\section{EXPERIMENTAL}

In an attempt to investigate some of these relationsips, two grazing trials were undertaken on.permanent ryegrass-white clover pasture at Massey University ('Grasslands, Ariki' ryegrass and 'Grasslands Huia' white clover) during the 1972-3 season. In these trials the length of the spelling period was based not on a predetermined time schedule but on canopy density, as determined by light penetration into the sward. Spelling period was therefore dependent on growth rate, and varied during different seasonis.

In Experiment 1 pastures were grazed by sheep from September to mid-December according to the following defcliation regimes :

*Research undertaken while on BP Scholarship and sabbatical leave from the Department of Pasture Science, University of Natal, South Africa. 
Treatment 1: Frequent hard grazing. Grazed to $2.5 \mathrm{~cm}$ above ground level whenever pasture attained full canopy as defined by interception of $95 \%$ of incoming light at midday.

Treatment 2: Infrequent 'hard grazing. Grazed to $2.5 \mathrm{~cm}$ two weeks after attainment, of full canopy.

Treatment 3: Infrequent lenient grazing. Grazed to $6.2 \mathrm{~cm}$ two weeks after attainment of full canopy.

While the terms "frequent", "infrequent", "hard" and "lenient" are, of course, relative, they are used here for convenience of reference .

Production in each treatment was measured at weekly intervals during the recovery period according to the following method: Three $6.2 \mathrm{~cm}$ by $1.65 \mathrm{~m}$ quadrats were harvested at ground level in each paddock. The herbage was washed free of soil, a sub-sample of approximately 10 grams retained for botanical analysis, and the remainder oven dried and weighed. The $10 \mathrm{~g}$ sub-sample was separated into four components - dead material, grass leaf (lamina), clover leaf, and stubble. After leaf area had been determined on both grass and clover samples, the material was oven dried and weighed. Growth during rhe grazing period was measured in caged areas within each paddock.

In Experiment 2 an attempt was made to vary grazing intensity within a single treatment in tan effort to alternately satisfy different requirements of rhe plants in the sward. Following the recovery of the pasture to full canopy after the first substantial autumn rains in March, 1973, the pastures were differentially grazed to either $2.5 \mathrm{~cm}$ or $6.2 \mathrm{~cm}$ on April 4. Both treatments were then grazed to $2.5 \mathrm{~cm}$ when full canopy had once again developed. Recovery growth was measured at weekly intervals, as in the first experiment, until the experiment was terminated on Tune 26.

Observations of tiller density and morphology were made during both experiments.

\section{RESULTS}

EXPERIMENT 1

As shown in Fig. 1, growth rate (from October to midDecember) varied from an average of only $5 \mathrm{~kg} \mathrm{DM} / \mathrm{ha} /$ day during the week following grazing on pastures grazed hard buf infrequently (approximately 7 -week intervals) to $40 \mathrm{~kg} / \mathrm{ha} /$ day on pastures grazed leniently but at more frequent intervals (ap- 


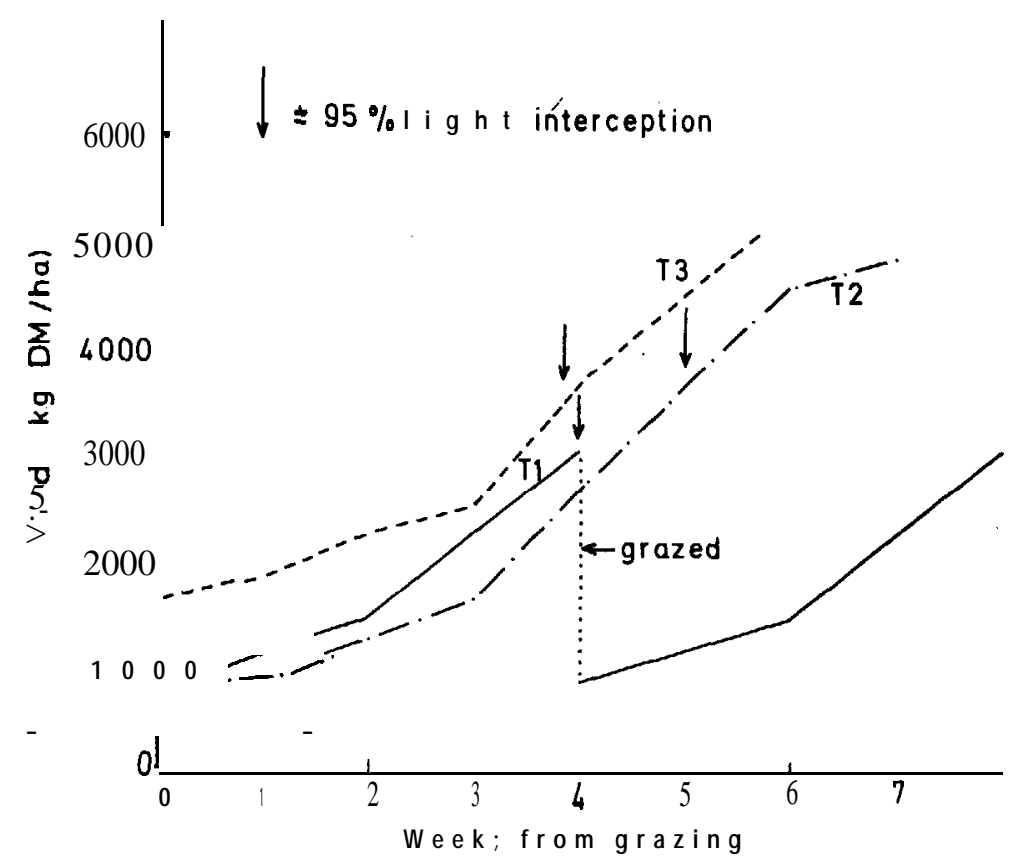

Fig. 1: Recovery growth in three different grazing rotations.

$\mathrm{T},=$ 'grazed to $2.5 \mathrm{~cm}$ at full canopy

$\mathrm{T}_{2}=$ grazed to $2.5 \mathrm{~cm}$ two weeks after full canopy

$\mathrm{T}_{3}=$ grazed to $6.2 \mathrm{~cm}$ two weeks after full canopy

proximately 4-week intervals). Initial recovery growth on pastures grazed both leniently and infrequently (approximately 51/2-week intervals) 'averaged $33 \mathrm{~kg} / \mathrm{ha} /$ day. During this time reproductive stem growth was prominent in the ryegrass component of the sward (Tainton, 1974).

Growth rate increased during the recovery period in all treatments until full canopy was attained, reaching values in excess of $160 \mathrm{~kg} / \mathrm{ha} / \mathrm{day}$ in all treatments, and then declining in those which remained ungrazed for a further two weeks. In those paddocks grazed hard two weeks after full canopy had been attained, production averaged $92.6 \mathrm{~kg} / \mathrm{ha} /$ day, cómpared with $96.0 \mathrm{~kg} / \mathrm{ha} /$ day in pastures which were grazed leniently at the same stage of canopy development. Where pastures were grazed leniently immediately full canopy was attained, production averaged $103.4 \mathrm{~kg} / \mathrm{ha} / \mathrm{day}$. This treatment yielded, over the October and 


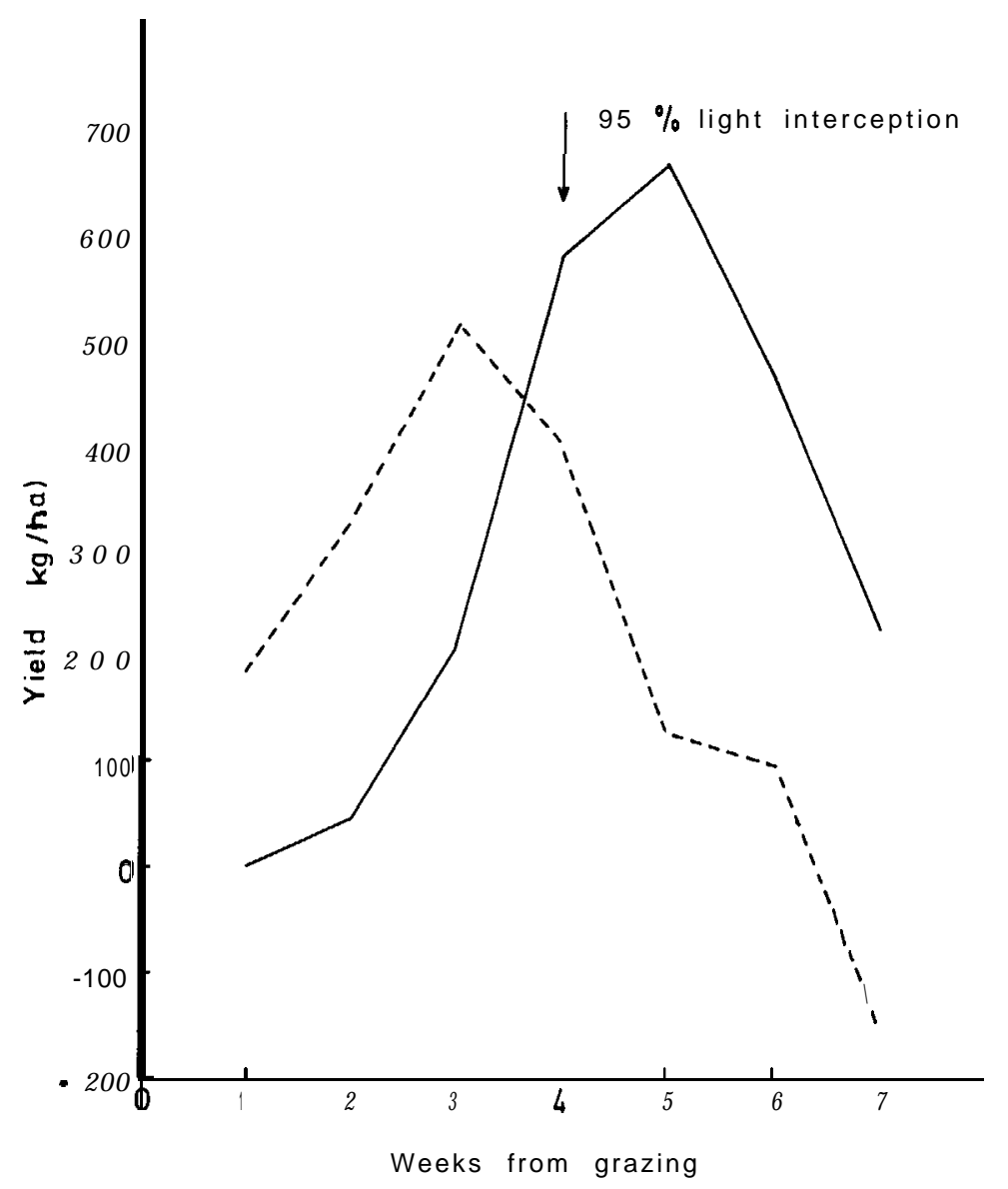

FIG. 2: Weekly increment in the dry weight oj the grass leaf (- $\left.-{ }_{-}-\right)$ and of the sheath and stern fraction (- averaged over all treatments.

November pericd, scme 650 and $450 \mathrm{~kg}$ more dry matter per ha than the less frequently grazed pastures. Also, since rates of leaf senescence increased rapidly from about the time that full canopy was attained, dead material made up a relatively larger proportion and living leaf a smaller proportion of the material presented to the animals in the two long rotations. In none of the treatmeats did clover contribute substantially to the yield (Table 1). 
TABLE 1: BOTANICAL COMPOSITION OF HERBAGE AT THE TIME OF GRAZING IN THREE DIFFERENT PASTURE ROTATIONS $(\%)$

\begin{tabular}{|c|c|c|c|c|c|}
\hline Trwtment & Stubble & Clover Leaf & Grass Leaf & Dead & Material \\
\hline 1 & 41.3 & 3.2 & 41.9 & & 13.6 \\
\hline 2 & 44.1 & 2.3 & 29.9 & & 23.7 \\
\hline 3 & 47.4 & 3.5 & 29.5 & & 19.4 \\
\hline
\end{tabular}

Common to all treatments was the dominance of leaf growth over stem and sheath growth during the first three weeks of the recovery period, followed by a period of rapidly declining leaf growth and the dominance of sheath and stem growth (Fig. 2). The growth rate of this component also declined, however, once the canopy had closed.

Estimates of tiller density indicated a thinning out of the pasture where grazing was infrequent. Young tillers often failed to survive in the dense canopy which developed. On these pastures also, the sheep were unable to cope adequately with long mature pasture, particularly in wet weather, and the mat of material which was trampled on to the soil surface caused plant death in patches within the pasture.

Lenient grazing compounded the effect of loag rotations on tiller density. It induced the formation of new tillers on elevated nodes of decapitated stems rather than at the base of the old tillers and these elevated tillers often failed to survive for any length of time.

\section{EXPERIMENT 2}

Paddocks which were leniently grazed early in April retained a large number of young green leaves which may have contributed substantially, through continued photosynthesis, to the rapid growth rate which followed grazing. Recovery growth in this treatment averaged $17 \mathrm{~kg} / \mathrm{ha} /$ day more than that of the pastures grazed hard on the same day. This response to lenient grazing in early April continued into the next cycle of the rotation, with the growth rate following hard grazing on April 30 end those plots lightly grazed in the previous cycle averaging $36.4 \mathrm{~kg} / \mathrm{ha}$,; day over the 41-day period until June 26. By comparison, the growth rate following the second grazing on paddocks hard grazed on both April 4 and May 10, averaged only $17.6 \mathrm{~kg} / \mathrm{ha} /$ day. The overall advantage of alternate lax and hard grazing over hard 
grazing, during the period April 4 to June 26, was $1404 \mathrm{~kg} / \mathrm{ha}$, or an increase of $63.6 \%$ in the production of harvestable material. This advantage resulted from the development of larger tillers (with better developed root systems) on those paddocks which had been leniently grazed in early autumn. No differences in tiller density were recorded between treatments during the experimental period.

\section{DISCUSSION}

The results of the late-spring/early-summer (experiment indicated that grazing of permanent ryegrass/white clover pasture should not be delayed beyond the development of full canopy. Not only did the growth rate decline rapidly after full canopy had been attained, but the rate of leaf senescence increased together with a reduction in tiller density which may be attributable to the failure of young tillers to survive when growing in dense shade. If, however, pastures are allowed tc develop to such a mature stage they should then be grazed hard. Lax grazing apparently leads to a further thinning out of the sward while any leaf which may deliberately be left on the pasture to encourage rapid regrowth through continued photosynthesis senesces rapidly cn exposure to light. Where, however, the pasture was grazed immediately full canopy had been attained and before the base of the sward had been subjected to dense shade, lax grazing not only ensured rapid recovery but was also not noticeably detrimental to the density of the pasture, at least in comparison with the cther treatments which were applied. Such results lend support to the earlier findings of Brougham (1959). However, continued lax grazing may, even in a rapid rotation, eventually lead to sward degeneration. Intermittent hard grazing may therefore be necessary to regenerate the sward.

It was to investigate this aspect that the autumn experiment involving a comparison of 'alternate lax and hard grazing with repeated hard grazing was initiated. This experiment showed that a single lenient grazing treatment applied in early autumn, when the pasture was made up almost exclusively of young vegetative tillers, assisted materially in the development of these tillers into a vigorous population which yielded considerably more dry matter through the autumn and early winter than did thcae which had been repeatedly hard grazed. The subsequent hard grazing treatment, by removing accumulated dead material at the base of the sward, stimulated continued tiller development. On the evidence of the spring experiment, the survival of a majority of 
these young tillers would be endangered if the canopy were then allowed to remain dense for any length of time. Paddocks should therefore be grazed at the time of or immediately before full canopy develops.

For maximum production during the autumn and early winter, therefore, a system of alternate lax and hard grazing at the time of canopy closure is recommended. The advisability of continuing such a rotation through late winter to the time of inception of reproductive growth in the spring has yet to be established. The necessity for intermittent hard grazing of a predominantly perennial ryegrass pasture would seem to depend on the requirement for continued tillering and on the extent to which repaated lax grazing would reduce sward density of clover growth and so lead to poor production during the following summer.

\section{ACKNOWLEDGEMENTS}

To Prof. B. R. Watkin, Department of Agronomy, Massey University, for facilities and advice, both technical and editorial; Dr M. J. Hill for his assistance; and BP Southern Africa for their financial assistance.

\section{REFERENCES}

Brougham, R. W., 1959: N.Z. Jl agric. Res., 2: 123.

Tainton, N. M., 1974: J, Br. Grassid Soc. (In press). 